\title{
Pushing resistance theory in IR beyond 'opposition': The constructive resistance of the \#MeToo movement in Japan
}

\author{
Mona Lilja \\ School of Global Studies, University of Gothenburg, Sweden \\ Corresponding author. Email: mona.lilja@gu.se
}

(Received 2 March 2020; revised 7 September 2021; accepted 14 September 2021; first published online 8 October 2021)

\begin{abstract}
This article aims to specifically contribute to debates concerning dissent within the scholarship of International Relations (IR), through elaborating the constructive qualities of resistance. Composite and fruitful stories concerning resistance against power have flourished in studies of the 'global'. Still, there has been a trend in IR to embrace resistance as a sense of opposition and it has been primarily described in terms of, "counter", "contradict", "social change", "reject", "challenge", 'opposition", "subversive", and "damage and/or disrupt". ${ }^{1}$ This article adds to the literature on resistance's productive dimensions by drawing upon the case of the \#MeToo campaign in Japan. The \#MeToo movement in Japan should not only be viewed as a 'non-cooperative' form of resistance - that is, resistance that breaks norms, rules, laws, regulations and order, typically in public and in confrontative ways; rather, the \#MeToo movement should be regarded as a 'constructive' form of resistance, which produced new resistance figures, movements, narratives as well as established new expressions of resistance. It may be perceived as a contagious form of resistance, which operated through reiterations, doublings, and re-experiences. The campaign provides a significant example of how discourses move transnationally through the force of repetition.
\end{abstract}

Keywords: Resistance; \#MeToo; Constructive Resistance; Japan; Gender; International Relations

\section{Introduction}

The \#MeToo campaign against sexual abuse began in the United States (US) and spread virally across the world during 2017. On a global scale, the resistance practices of the \#MeToo movement produced new - although still discursively anchored, and thereby intelligible - narratives of sexual abuse. $^{2}$ The movement connected people to each other, decided who should be regarded as victims or perpetrators, and contributed to the creation of communities of belonging - wherein some people experienced that they fitted in, whereas others did not. This indicates that the resistance practices of the \#MeToo movement should not only be viewed as a 'non-cooperative' form of resistance - that is, resistance that breaks norms, rules, laws, regulations and order, typically in public and in confrontative ways; rather, the \#MeToo movement should be regarded primarily as

\footnotetext{
${ }^{1}$ Jocelyn A. Hollander and Rachel L. Einwohner, 'Conceptualizing resistance', Sociological Forum, 19:4 (2004), pp. 533-54 (p. 538).

${ }^{2}$ Mona Lilja and Evelina Johansson, 'Feminism as power and resistance: An inquiry into different forms of Swedish feminist resistance and anti-genderist reactions', Social Inclusion, 6:4 (2018), pp. 82-94.

(C) The Author(s), 2021. Published by Cambridge University Press on behalf of the British International Studies Association. This is an Open Access article, distributed under the terms of the Creative Commons Attribution licence (https://creativecommons.org/licenses/by/4.0/), which permits unrestricted re-use, distribution, and reproduction in any medium, provided the original work is properly cited.
} 
a 'constructive' form of resistance, which produced new resistance figures, movements, and narratives, and established new expressions of resistance.

This article aims to specifically contribute to debates concerning resistance within the scholarship of International Relations (IR), through elaborating the constructive qualities of resistance. Composite and fruitful stories concerning resistance against power have flourished in IR and studies of the 'global'. However, as I will further discuss in the forthcoming sections, there has been a trend in IR to embrace resistance as a sense of opposition and it has been primarily described in terms of, "counter", "contradict", "social change", "reject", "challenge", "opposition", "subversive", and "damage and/or disrupt". ${ }^{3}$ In addition, the abundant production of IR literature on mobilisations can be understood as divided into more or less distinct subfields. While one major trend is to analyse collective action, during the last decades this has been complemented with research on 'hidden agency', as well as on the relationship between power and resistance. ${ }^{4}$ While, this bulk of research has been novel, the scope of resistance studies within the field of IR still needs further engagement. As suggested by Majken Jul Sørensen, 'surprisingly little' has been written about, 'initiatives which not only criticize, protest, object, and undermine what is considered undesirable and wrong, but simultaneously acquire, create, built, cultivate and experiment with what people need in the present moment, or what they would like to see replacing dominant structures or power relations. ${ }^{5}$ In this article I argue that it is time to add to the IR scholarship by further elaborating on the 'constructive' mode of resistance.

Contemporary research contains some attempts to move in this direction. The difference here, in this article, lies in attention to that which is constructed. While some scholars posit that constructed resistance is about the construction of alternative organisations, institutions, or communities, another line of reasoning frames resistance in the form of counternarratives. ${ }^{6}$ However, this divide must be dissolved in order to recognise that constructive resistance produces both knowledge, subjectivities, and alternative institutions.

Below, I discuss resistance's constructive character by elaborating the case of the \#MeToo campaign in Japan, which was upheld by only a few narrators; among them, journalist and filmmaker Itō Shiori. The question is, how should we - as a collective of engaged IR scholars - inquire about the resistance of the \#MeToo movement, which has wrenched gendered images, while suggesting

\footnotetext{
${ }^{3}$ Jocelyn A. Hollander and Rachel L. Einwohner, 'Conceptualizing resistance', Sociological Forum, 19:4 (2004), pp. 533-54 (p. 538).

${ }^{4}$ Catherine Eschle and Bice Maiguashca, 'Rethinking globalised resistance', The British Journal of Politics and International Relations, 2:6 (2007), pp. 284-301; David Armstrong, Theo Farrell, and Maiguashca, Governance and Resistance (Cambridge, UK: Cambridge University Press, 2004); James C. Scott, 'Everyday forms of resistance', Copenhagen Papers, 4 (1989), pp. 3362; James C. Scott, Domination and the Arts of Resistance (New Haven, CT and London, UK: Yale University Press, 1990); Asaf Bayat, Street Politics: Poor People's Movements in Iran (Cairo, Egypt: The American University in Cairo Press, 1997); Anna Johansson and Stellan Vinthagen, Conceptualizing 'Everyday Resistance': A Transdisciplinary Approach (New York, NY: Routledge, 2019); Bice Maiguashca, 'Governance and resistance in world politics', Review of International Studies, 29 (2003), pp. 3-28.

${ }^{5}$ Majken Jul Sørensen, ‘Constructive resistance: Conceptualising and mapping the terrain', Journal of Resistance Studies, 2:1 (2016), pp. 49-78 (p. 57); see also Eschle and Maiguashca, 'Rethinking globalised resistance'; Armstrong, Farrell, and Maiguashca, Governance and Resistance; Minoo Koefoed, 'Constructive resistance in northern Kurdistan: Exploring the peace, development and resistance nexus', Journal of Peacebuilding \& Development, 12:3 (2017), pp. 39-53 (p. 42); Mona Lilja and Stellan Vinthagen, 'Dispersed resistance: Unpacking the spectrum and properties of glaring and everyday resistance', Journal of Political Power, 11:2 (2018), pp. 211-29, available at: \{https://www.tandfonline.com/doi/full/10.1080/2158379X. $2018.1478642\}$ accessed 3 September 2021.

${ }^{6}$ See, for example, Minoo Koefoed, 'Martyrdom and emotional resistance in the case of northern Kurdistan: Hidden and public emotional resistance', Journal of Political Power, 10:2 (2017), pp. 184-99; Roland Bleiker, Popular Dissent, Human Agency and Global Politics (Cambridge, UK: Cambridge University Press, 2000); Mona Lilja, Constructive Resistance: Repetitions, Emotions and Time (London, UK and New York, NY: Rowman \& Littlefield International, 2021); Kristen Wiksell, 'Worker cooperatives for social change: Knowledge-making through constructive resistance within the capitalist market economy', Journal of Political Power, 2 (2020), pp. 201-16.
} 
new forms of resistance, activist figures, and activism? Indeed, from the insights that the \#MeToo resistance produced, we must critically reconsider how to theorise resistance.

More generally, the \#MeToo movement created a sense of belonging on a global scale, given that individual resistance was practiced as a serial phenomenon. Single acts of resistance were undertaken by loosely connected individuals who shared similar interests or experiences, which produced and conveyed the campaign's collectiveness. However, in the media in Japan, Itō Shiori was often referred to as the only figurehead for the \#MeToo campaign. Given this, Itō Shiori not only came to experience the punishments that are distributed for resisting sexual violence but her entire identity as a 'Japanese woman' was questioned. Moreover, certain frictions emerged between Itō Shiori as a 'resister' and a (re)appearing Japanese figuration of the female resister, who publicly targets issues such as food that contains additives, the application of pesticides in the environment, and the use of nuclear energy, typically to protect their children and those of others. ${ }^{7}$ Still, Itō Shiori, and other \#MeToo profiles in Japan, contributed to, firstly, producing new narratives in Japan that place (society-defined) women in the context of power networks and sexual violence (narratives that are now being maintained and advanced by organisations such as Flower Demo, Spring, or Voice Up Japan). Secondly, Itō Shiori came to embody a new figure of the resister, which others have performed in her wake. Furthermore, she and others contributed to establishing the specific configuration of resistance - the hashtag has become a symbol in Japanese society that is currently filled with other political connotations; for instance, in the \#KuToo, \#KimOhNo, and the \#WithYou campaigns. ${ }^{8}$ The above-mentioned bearings of the Japanese \#MeToo campaign will be further interrogated below in terms of: (1) alternative discourses; (2) the establishment of an alternative resistance figure and movements; as well as (3) new configurations of resistance.

Here, it is important to take a pause and point out that the various discourses, figures, or configurations that are suggested in the moment of resistance, when read and received, are both contested as well as unstable constructions. The discourses advanced by the \#MeToo movement in Japan, for example, are neither dominant nor clear-cut; rather, they are interpreted though other perspectives, developed, mixed, or added to as they are decoded and forwarded. Accordingly, it cannot be underscored enough that the figures and configurations of resistance brought about by Japan's \#MeToo movement are neither fixed nor governing. When identifying how, in the meeting between more local and more universal discourses, different encounters and frictional processes have created new agencies, ideas, and practices in Japan, we must also emphasise the slipperiness and complexity of such constructions. ${ }^{9}$ Constructive forms of resistance are played out in contexts of different epistemic battles, which are important to investigate. Indeed, the \#MeToo movement should be addressed as a complex resistance movement that, according to postcolonial and IR scholar Swati Parashar, 'should not be seen as an unambiguous space of women's activism and feminist solidarities but ... has also been marked by anxieties and frustrations. ${ }^{10}$

The arguments in this article are constructed from a number of secondary sources. On the one hand, scholarly books and papers have been embraced, which have proven to be both inspirational and informative in assisting me to identify feminist political actions. Among these, I

\footnotetext{
${ }^{7}$ Mikiko Eto, 'Women's movements in Japan: The intersection between everyday life and politics', Japan Forum, 17:3 (2005), pp. 311-33.

${ }^{8}$ Claude Lévi-Strauss, Introduction to the Work of Marcel Mauss (London, UK: Routledge and Kegan Paul, 1987 [orig. pub. 1959, in French]), p. 63.

${ }^{9}$ Anna Lowenhapt Tsing, Friction: An Ethnography of Global Connections (Princeton, NJ: Princeton University Press, 2005); Annika Björkdahl and Kristine Höglund, 'Precarious peacebuilding: Friction in global-local encounters', Peacebuilding, 1:3 (2013), pp. 289-99.

${ }^{10}$ Swati Parashar, 'The \#MeToo Movement and Postcolonial Feminist Dilemmas: Reflections from India', School of Global Studies, University of Gothenburg (30 January 2019), available at: \{https://www.blogalstudies.com/post/the-metoomovement-and-postcolonial-feminist-dilemmas-reflections-from-india\} accessed 1 September 2020.
} 
have based my results upon the alternative media produced by feminist scholars and activists in Japan over the last few decades, which I located through venues, such as, the Women's Action Network (WAN), the Asian Women's Resource Center, and organisations such as the Tokyo Rape Crisis Center. On the other hand, I have drawn upon Itō Shiori's representations of her story (and how it has been received), as published through different media channels.

The secondary sources have been combined with interviews that were carried out with some 35 civil society and social movement actors in Tokyo in 2013 and 2014, among them feminist organisations, such as the Asian Women's Resource Center. Additionally, some complementary interviews were carried out via Messenger, Google Meet, Zoom, and via email in 2019 and 2020 with activists, feminist scholars, and feminist organisations; for example, Flower Demo and Voice Up Japan. Together, the numerous primary and secondary sources form rich and differentiated material that is characterised by competing and contradictory stories. ${ }^{11}$

\section{Resistance in the scholarship of International Relations: Introducing the notion of constructive resistance}

Considering the transnational format of the \#MeToo movement, this kind of resistance should be elaborated within the field of IR. Currently, the resistance literature within IR serves us with a composite landscape with its own particular features. More generally, there has been a curious focus on organised and collective resistance, which is sometimes considered the only wellequipped resistance to serve as an engine of 'real' social change. ${ }^{12}$ Among others, the popular theory of 'contentious politics' excludes acts by small groups of individuals from what they count as 'events' and explicitly limits the scope to forms of contention that display 'public, collective interaction'. ${ }^{13}$ However, when sketching the intellectual terrain of resistance in IR, what is revealed is that it has been redrawn significantly during the last decades - the scope has been broadening and there have been innovations within the study of agency. One topic that has attracted attention from the IR scholarship has been the relationship between power and resistance. ${ }^{14}$ Bice Maiguashca, among others, argues that it is of vital interest for current researchers to understand the relationship between two forms of politics; the politics of governance and the politics of resistance, where the latter consists of various transnational civil-society actors, including social movements and non-governmental organisations (NGOs), as well as, at least potentially, coalitions of states from the Global South. ${ }^{15}$ Lara Montesinos Coleman and Karen Tucker further elaborate on this theme by suggesting that not only power but also contextual factors, such as local discourses and subjectivities, impact upon how the resistance is played out. ${ }^{16}$ Brooke A. Ackerly, Elisabeth Jay Friedman, Krishna Menon, and Marysia Zalewski, in a similar vein, suggest that feminist IR, by constructing modes of oppression, pinpoints the possible paths of resistance. For example, understanding global politics through the postcolonial binary sometimes

\footnotetext{
${ }^{11}$ I have also taken measures to protect my respondents. When requested, the names of the respondents remain secret.

${ }^{12}$ Mona Lilja and Mikael Baaz, "The unfortunate omission of entangled resistance in the "local turn" in peace-building: the case of "forced marriage" in the Extraordinary Chambers in the Courts of Cambodia (ECCC)', Conflict, Security \& Development, 21:3 (2021), pp. 273-92; Mikael Baaz, Mona Lilja, Michael Schulz, and Stellan Vinthagen, 'Civil resistance for peace and conflict managements, role of, in Oliver Richmond and Gëzim Visoka (eds), The Palgrave Encyclopedia of Peace and Conflict Studies (Basingstoke, UK: Palgrave Macmillan, 2021).

${ }^{13}$ Doug McAdam, Sidney Tarrow, and Charles Tilly, Dynamics of Contention (Cambridge, UK: The Press Syndicate of the University of Cambridge, 2001), p. 4.

${ }^{14}$ Scott, 'Everyday norms of resistance'; Scott, Domination and the Arts of Resistance; Bayat, Street Politics; Mona Lilja and Stellan Vinthagen, 'Sovereign power, disciplinary power and biopower: Resisting what power with what resistance?', Journal of Political Power, 7:1 (2014), pp. 107-26.

${ }^{15}$ Maiguashca, 'Governance and resistance in world politics'; Eschle and Maiguashca, 'Rethinking globalised resistance'; Armstrong, Farrell, and Maiguashca, Governance and Resistance.

${ }^{16}$ See also Lara Montesinos Coleman and Karen Tucker (eds), Situating Global Resistance: Between Discipline and Dissent (Abingdon, UK: Routledge, 2012).
} 
conceals the complexities of privilege and the 'resistance politics are imbricated in the disciplinary conversations of the field'. ${ }^{17}$

Over and above this, another contemporary trend within the study of resistance in IR is to locate more hidden or less dramatic forms of agency. Scholars such as Oliver Richmond and Roger Mac Ginty have debunked the common storyline of resistance in IR, by highlighting types of resistance that are generally not manifested in expressly political registers. ${ }^{18}$ They have, together with other researchers within Peace Studies and Conflict Studies within IR, by drawing foremost on the theories of Michel de Certeau and James Scott, depicted resistance as a reaction against what is considered as problematic peace interventions. ${ }^{19}$ According to Oliver Richmond, the field locates how, 'millions of people around the world renegotiate the terms of their political lives daily in small ways, through forms of resistance designed to alter this system in order to represent them'. ${ }^{20}$ As Elisa Randazzo describes it, the new 'local turn' involves the rethinking of peacebuilding where, 'the shift away from top-down implies accepting the importance of local agency, and of the contingencies of the post-conflict milieu'. ${ }^{21}$ Putting local, hidden, or everyday agency in focus has resulted in more elaborated studies of peacebuilding and thus provides some avenues through which we can begin to interrogate processes of reconciliation. ${ }^{22}$

The above vernacular has contributed with several insights regarding different forms of resistance, as well as the crossroads between power and resistance; still, one weakness of the scholarship on resistance in IR is the rather limited focus so far. Among other things, there is a conspicuous absence in most studies in IR on the entanglements between more individual expressions of resistance and collective mobilisations. ${ }^{23}$ In addition, few scholars have pursued a route over the 'building' aspects of resistance. Or as expressed by Minoo Koefoed, there has been a tendency for social science scholars to equate resistance in narrow and negative terms as actions "being against", "in opposition", or "saying no"'. ${ }^{24}$ With this as a backdrop, critics have argued that

\footnotetext{
${ }^{17}$ Brooke A. Ackerly, Elisabeth Jay Friedman, Krishna Menon, and Marysia Zalewski, 'Vectors and warp speed: Hypermasculinity on the rise, once again?', International Feminist Journal of Politics, 23:1 (2021), pp. 1-4.

${ }^{18}$ Johansson and Vinthagen, Conceptualizing 'Everyday Resistance' A Transdisciplinary Approach; Oliver Richmond, 'Resistance and the post-liberal peace', Millennium, 38:3 (2010), pp. 665-92; Roger Mac Ginty, International Peacebuilding and Local Resistance: Hybrid Forms of Peace (Basingstoke, UK: Palgrave Macmillan, 2011).

${ }^{19}$ Roberto Belloni, Stefanie Kappler, and Jasmin Ramovic, 'Bosnia-Herzegovina: Domestic agency and the inadequacy of the liberal peace', in Oliver Richmond and Sandra Pogodda (eds), Post-Liberal Peace Transitions: Between Peace Formation and State Formation (Edinburgh, UK: Edinburgh University Press, 2016), pp. 47-64; Michael Pugh, 'Local agency and political economies of peacebuilding', Studies in Ethnicity and Nationalism, 11:2 (2011), pp. 308-20; Richmond, 'Resistance and the post-liberal peace'; Mac Ginty, International Peacebuilding and Local Resistance; Johansson and Vinthagen, Conceptualizing 'Everyday Resistance'; Marta Iñiguez de Heredia, 'Everyday Resistance in Post-Conflict Statebuilding: The Case of Eastern Democratic Republic of Congo' (PhD dissertation, Department of International Relations, The London School of Economics and Political Science, 2013).

${ }^{20}$ Oliver Richmond, 'Critical agency, resistance and a post-colonial civil society', Cooperation and Conflict, 46:4 (2011), pp. 419-40 (pp. 435-36); Marta Iñiguez de Heredia, Everyday Resistance, Peacebuilding and State-Making: Insights from Africa's World War (Manchester, UK: Manchester University Press, 2017).

${ }^{21}$ Elisa Randazzo, 'The paradoxes of the "everyday": Scrutinising the local turn in peace building', Third World Quarterly, 37:8 (2016), pp. 1351-70.

${ }^{22}$ See, for example, Oliver Richmond, 'Becoming liberal, unbecoming liberalism: Liberal-local hybridity via the everyday as a response to the paradoxes of liberal peacebuilding', Journal of Intervention and Statebuilding, 3:3 (2009), pp. 324-44: Roger Mac Ginty, 'Introduction: The transcripts of peace: Public, hidden or non-obvious?', Journal of Intervention and Statebuilding, 7:4 (2013), pp. 423-30.

${ }^{23}$ Lilja and Baaz, 'The unfortunate omission of entangled resistance in the "local turn"'; Mona Lilja, Mikael Baaz, Michael Schulz, and Stellan Vinthagen, 'How resistance encourages resistance: Theorising the nexus between power, everyday resistance and organized resistance', Journal of Political Power, 1:1 (2017), pp. 40-54.

${ }^{24}$ Koefoed, 'Constructive resistance in northern Kurdistan', p. 42; Stephen Duncombe, Cultural Resistance Reader (London, UK: Verso, 2002); Lilja, Constructive Resistance: Repetitions, Emotions and Time; Mona Lilja, 'Theoretical suggestions for future research on constructive resistance: Strategies of representation of the Japanese civil society', Journal of Political Power, 13:2 (2020), pp. 217-32.
} 
contemporary research neglects resistance that establishes alternatives, thereby replacing hegemonic constructions or power relations. ${ }^{25}$ This side-stepping opens up a gap for this article to fill; we must expand the boundaries and content of the study of resistance within IR. Dissent is not simply in opposition to, destructive against, or critical of the prevailing order, but also has a constructive mode. The current take on resistance, while being novel and rich, is still somewhat restrained, and I would like to argue that the scholarship is not yet fully equipped to deal with various aspects of constructive resistance.

A few researchers have recently taken the opportunity to engage in the constructive mode of resistance. Foremost, scholars such as Koefoed and Sørensen ${ }^{26}$ address the constructive mode of collective action and the establishment of alternative institutions, thus largely omitting resistance that disturbs current knowledge regimes by promoting new truths and subjectivities. Koefoed, for example, considers how the Kurdish movement in Turkey's Kurdish region have undertaken constructive resistance by establishing self-organised Kurdish primary schools and Kurdish language schools for adults, both being semi-illegal institutions. ${ }^{27}$

Knowledge-making as resistance has been elaborated by other scholars, although without explicitly discussing the constructive aspects of it. Notable scholars within IR, such as Roland Bleiker, ${ }^{28}$ have waged a critique of the focus on organised resistance, thereby, opening up space for practices of dissent that 'work in discursive ways, that is, by engendering a slow transformation of values' ${ }^{29}$ In a similar vein, some IR researchers have interrogated meaning-making resistance through the Foucauldian concept of counter-conducts. Helle Malmvig, for example, analyses the battle for Syria by conceptualising creative visual counter-conducts as practices that produce alternative modes of being seen. ${ }^{30}$ Moreover, one of Carl Death's articles discusses the South African youth movement and shows how counter-cultural practices work in productive ways to subvert dominant ways of being. ${ }^{31}$ Even if not explicitly highlighting the productive aspects of resistance, but rather framing the resistance as resistance that are generally not 'manifested in expressly political registers', this scholarly literature, while limited to the concept of counter-conducts, still pinpoints some constructive aspects of resistance and more generally paves the way for acknowledging how Foucauldian approaches support thinking about resistance within IR. ${ }^{32}$ The research of Bleiker, Death, Malmvig, mentioned above, also relates to and sometimes draws on the many specialist fields that it engages with or is inspired by, such as: Gender Studies and Feminism, Queer Studies, Critical Race Studies, Sociology, and Postcolonial and Decolonial Studies. ${ }^{33}$ Some of

\footnotetext{
${ }^{25}$ Sørensen, 'Constructive resistance', p. 57; Minoo Koefoed, 'The Art of Enacting the Impossible: A Conceptual, Empirical, and Methodological Exploration of Constructive Resistance by the Kurdish Movement in Turkey' (PhD dissertation, School of Global Studies, University of Gothenburg, 2018).

${ }^{26}$ Koefoed, 'The Art of Enacting the Impossible'; Sørensen, 'Constructive resistance'; David Butz and Michael Ripmeester, 'Finding space for resistant subcultures', Visible Culture: An Electronic Journal for Visual Studies, 2 (1999), pp. 1-19; Kerem Nişancıoğlu and Maïa Pal, 'Counter-conduct in the university factory: Locating the Occupy Sussex campaign', Global Society, 30:2 (2016), pp. 279-300.

${ }^{27}$ Koefoed, 'Constructive resistance in northern Kurdistan'.

${ }^{28}$ Bleiker, Popular Dissent.

${ }^{29}$ Ibid., p. 276.

${ }^{30}$ Helle Malmvig, 'Eyes wide shut: Power and creative visual counter-conducts in the battle for Syria, 2011-2014', Global Society, 30:2 (2016), pp. 258-78.

${ }^{31}$ Carl Death, 'Counter-conducts as a mode of resistance: Ways of "not being like that" in South Africa', Global Society, 30:2 (2016), pp. 201-17.

${ }^{32}$ Louiza Odysseos, Carl Death, and Helle Malmvig, 'Interrogating Michel Foucault's counter-conduct: Theorising the subjects and practices of resistance in global politics', Global Society, 30:2 (2016), pp. 151-56 (p. 151), available at: \{https://doi org/10.1080/13600826.2016.1144568\}.

${ }^{33}$ See, for example, Amanda Källstig and Carl Death, 'Laughter, resistance and ambivalence in Trevor Noah's stand-up comedy: Returning mimicry as mockery', Critical African Studies, available at: \{https://doi.org/10.1080/21681392.2020. $1743191\}$.
} 
these fields elaborate on what has been addressed as 'subversive knowledge', 'counter-history' or 'knowledges otherwise'. ${ }^{34}$

Drawing on the above, I suggest that constructive resistance within IR has primarily been dealt with, although often unarticulated and implicit, as either the construction of alternative institutions or societies, or as the production of knowledge otherwise. This article adds to the debate captured above by highlighting how different practices of resistance have constructive aspects and produce not only collective action and movements or new knowledge and subjectivities, but both.

Constructive resistance could be seen as a response to power; a practice, 'that might undermine different modes and aspects of power in their enactments, performances and constructions of alternatives' ${ }^{35}$ It can be grand, but it can also be a matter of producing ongoing small-scale differences that might look trivial but sometimes have major impacts. ${ }^{36}$ The concept of 'constructive resistance', then, moves beyond non-cooperative forms of resistance that primarily oppose 'onedimensional power', decision-making or 'sovereign' power. ${ }^{37}$ I understand non-cooperative resistance as a typically public and confrontative form of resistance, which is involved in the breaking of norms, rules, laws, regulations, and order. ${ }^{38}$ However, as stated by Sørensen, 'Constructive resistance does not exclude conventional forms for protests, boycotts and civil disobedience, but focuses on creating, building, carrying out and experimenting .... ${ }^{39}$ Thus, many practices of resistance contain both constructive and non-constructive elements, and these indeed work together to undermine systems of domination. Sometimes, constructive resistance is 'more' constructive and less in opposition; it is a sliding scale. ${ }^{40}$

\section{The \#MeToo movement as feminist resistance}

The \#MeToo campaign was an international movement against sexual harassment, which started in the US and spread virally across the world during 2017. A number of scholars have displayed the positive effects of the \#MeToo movement, among them Aida Alvinius and Arita Holmberg, ${ }^{41}$ who found that it contributed to challenging hyper-masculine norms in the Swedish military. ${ }^{42}$

\footnotetext{
${ }^{34}$ Michel Foucault, The History of Sexuality: An Introduction, Vol. 1 (Harmondsworth, UK: Penguin, 1990); Ramón Grosfoguel, 'The structure of knowledge in Westernized universities epistemic racism/sexism and the four genocides/epistemicides of the long 16th century', Human Architecture, 10:1 (2013), pp. 73-90; Ramón Grosfoguel, 'Colonial difference, geopolitics of knowledge and global coloniality in the modern/colonial capitalist world-system', Review, 25:3 (2002), pp. 203-24; Walter D. Mignolo, 'Epistemic disobedience, independent thought and decolonial freedom', Theory, Culture \& Society, 26:7-8 (2009), pp. 1-23, available at: \{https://doi.org/10.1177/0263276409349275\}; Lilja, Constructive Resistance: Repetitions, Emotions and Time; Mona Lilja, Power, Resistance and Women Politicians in Cambodia: Discourses of Emancipation (Copenhagen, Denmark: Nias Press, 2008).

${ }^{35}$ Koefoed, 'Constructive resistance in northern Kurdistan', p. 43; Koefoed, 'The art of enacting the impossible', p. 59.

${ }^{36}$ Sørensen, 'Constructive resistance’.

${ }^{37}$ Stellan Vinthagen, Ickevåldsaktion En social praktik av mostånd och konstruktion (Gothenburg, Sweden: University of Gothenburg, 2005), available at: \{https:/gupea.ub.gu.se/bitstream/2077/16635/\} accessed 12 February 2019; Mona Lilja and Stellan Vinthagen, 'Resistance', in Gary L. Anderson and Kathryn G. Herr (eds), Encyclopaedia of Activism and Social Justice (London, UK: Sage, 2007), pp. 1215-17; Sørensen, 'Constructive resistance'; Koefoed, 'Martyrdom and emotional resistance'; Michel Foucault, Discipline and Punish: The Birth of the Prison (Harmondsworth, UK: Penguin, 1991 [orig. pub. 1975]); Majken Jul Sørensen and Kristin Wiksell, 'Constructive resistance to the dominant capitalist temporality', Sociologisk forskning, 56:3-4 (2019), pp. 253-74; Steven Lukes, Power: A Radical View (London, UK: Macmillan, 1974); Robert A. Dahl, Pluralist Democracy in the United States: Conflict and Consent (Chicago, IL: Rand McNally \& Company, 1967): Lilja, Constructive Resistance: Repetitions, Emotions and Time.; Lilja and Vinthagen, 'Sovereign power, disciplinary power and biopower'.

${ }^{38} \mathrm{Baaz}$ et al., 'Civil resistance for peace and conflict managements, role of.

${ }^{39}$ Sørensen, 'Constructive resistance', p. 57.

${ }^{40}$ Sørensen, 'Constructive resistance'.

${ }^{41}$ Aida Alvinius and Arita Holmberg, 'Silence-breaking butterfly effect: Resistance towards the military within \#MeToo', Gender Work and Organization, $26: 9$ (2019), pp. 1255-70.

${ }^{42}$ Ibid.
} 
In a similar vein, Kelly Wilz credits the \#MeToo campaign with the confronting of cultures of silence around sexual abuse. ${ }^{43}$ However, there are also scholars who have been more sceptical in regard to the \#MeToo movement, arguing that the movement must be read in the light of previous feminist research on intersectionality. ${ }^{44}$ According to Jo Hsu, the \#MeToo movement can be understood in terms of carceral politics, which fails to contain the many stories of people of colour, queer, transgender, poor, and/or disabled. The whole rhetoric of the \#MeToo movement, it is argued, requires survivors to narrate themselves as 'perfect victims', which produces inarticulable subjects and keeps them outside the resistance. ${ }^{45}$

Lisa M. Corrigan has similarly expressed concern over the fact that white women have been hijacking the hashtag that was started by a black woman, Tarana Burke. ${ }^{46}$ Moreover, Corrigan argued that the movement lacks a recognition of the lethal brutality that is often connected to sexual violence, and she organised the movement for 'the erasure of male victims, the lack of nuance about bidirectional violence, and disregard of sexual violence against LGBTQ people but especially transwomen of colour. ${ }^{47}$ She also questioned how the \#MeToo movement has sometimes come to revolve around the question of consent. First of all, current conceptualisations of consent imply that sexual violence is not intentional, which is not always the case. ${ }^{48}$ In addition, '[c] onsent, especially sexual consent, implies that people are peers. ${ }^{49}$

The above discussion displays the composite stories about race and class issues that the scholarship on the \#MeToo movement has produced. Additionally, it uncovers the topographies of the particular configuration of the \#MeToo movement, revealing how Itō's struggle and the Japanese \#MeToo campaign took place in a location other than Hollywood where celebrities started the campaign. Next, I interrogate the \#MeToo movement in the light of Japanese feminism and anti-genderism.

\section{Japanese feminism and anti-genderism on the rise}

The Meiji era (1868-1912), which is often defined as the beginning of 'modern' Japan, can be said to mark the beginnings of Japanese 'feminism', with activists such as Kishida Toshiko (18611901) and Fukuda Hideko (1865-1927). ${ }^{50}$ During the early twentieth century there was an upswing of women's groups. The women's suffrage movement in Japan, perpetuated by women like Ichikawa Fusae (1893-1981) and Oku Mumeo (1895-1997), was effective in creating a feminist discourse in the 1920s. However, other less radical groups were also active throughout this period, such as the Japanese branch of the Woman's Christian Temperance Union (Tokyo Fujin Kyōfūkai), which took on a number of challenges and worked actively against concubinage and prostitution. ${ }^{51}$

Many important texts have contributed to Japanese feminism. Among them, Hosoi Wakizo's 1952 book Jokõ aishi (The Pitiful Conditions of Women Workers), which illuminates some of the difficulties women could experience in the spinning and textile factories in the mid-twentieth century. The book can be seen as an illustration of how Japanese women became increasingly

\footnotetext{
${ }^{43}$ Kelly Wilz, Resisting Rape Culture through Pop Culture: Sex After \#MeToo (Lanham, MD: Lexington Books, 2019).

${ }^{44}$ Lisa M. Corrigan, 'The \#MeToo moment: A rhetorical zeitgeist', Women's Studies in Communication, 42:3 (2019), pp. 264-68, available at: \{https://doi.org/10.1080/07491409.2019.1652528\}; Hsu, '(Trans)forming \#MeToo'.

${ }^{45} \mathrm{Hsu}$, '(Trans)forming \#MeToo'; Rebecca Leung and Robert Williams, '\#MeToo and intersectionality: An examination of the \#MeToo movement through the R. Kelly scandal', Journal of Communication Inquiry, 43:4 (2019), pp. 349-71, available at: $\{$ https://doi.org/10.1177/0196859919874138/\} accessed 1 September 2020.

${ }^{46}$ Corrigan, 'The \#MeToo moment', p. 264.

${ }^{47}$ Ibid.

${ }^{48}$ Ibid.

${ }^{49}$ Ibid.

${ }^{50} \mathrm{Ibid}$.

${ }^{51}$ Ibid.
} 
exposed to sexual harassment as they became part of the work force at the beginning of the Industrial Revolution. ${ }^{52}$

The beginning of the 1970s may be considered a crucial time for Japanese feminism; a new wave of radical feminist activism, pervasively known as üman ribu (women's lib) emerged in conjunction with the continuation of state feminism through government institutions, such as the Women's Bureau. Although the üman ribu movement was rather small, it was highly influential in regard to the feminist movement in Japan. It claimed that the oppression against women involved a systematic privileging of men and masculinity and explained discrimination and oppression against women as being based on women's sex and sexuality. ${ }^{53} \mathrm{~A}$ six-page pamphlet, entitled Liberation from the Toilet, by one of üman ribu's key activists, Tanaka Mitsu, became the most well-known manifesto of the üman ribu movement. Among other things, Tanaka strongly argued that women's liberation had to be about the liberation of sex. This, according to scholar Setsu Shigematsu, makes her a forerunner theorist of the feminist movement in Japan. ${ }^{54}$

While the üman ribu movement was weakened and gradually disappeared during the latter part of the 1970s, feminist Japanese activists and academics continued to emphasise women's reproductive and sexual autonomy, although to a lesser extent. ${ }^{55}$

In October 1988, the release of the translated and published handbook Stopping Sexual Harassment shed new light on sexual abuse. On a similar note, in 1991, Gakuyõ Shobõ published the influential Onna 6,500 nin no shoggen ('The Testimony of 6,500 Women'), which contains the results of a major survey of 10,000 working women nationwide on the issue of sexual harassment (carried out by the Santama Area Group). These publications - together with a 1989 case of sexual harassment that a woman brought before the Fukuoka District Court - increasingly drew the public's attention to the practice of sexual harassment during the 1980s and 1990s. ${ }^{56}$ Overall, from the 1980s onward, several grassroots women's groups emerged to address the issues of rape, pornography, objectification of women in the media, and sexual harassment in different workplaces. The Tokyo Rape Crisis Center, the first rape crisis centre in Japan, was created in $1983 .{ }^{57}$ Christopher Uggen and Chika Shinohara ${ }^{58}$ have compared sexual harassment in the US and in Japan by outlining the following phases: (1) a stage from 1975 to 1987 when consciousness of sexual harassment, while emerging in the US, still got limited attention in Japan; (2) a stage from 1988 when sekuhara widespread public consciousness of sexual harassments - entered the Japanese discourse - still, during this period the sexual abuse discourse was more widespread in the US than in Japan; and (3) a stage from 1999 when the countries were nearly on the same level. ${ }^{59}$

\footnotetext{
${ }^{52}$ Tsunoda Yukiko and Yokokawa Muro Mariko, 'Sexual harassment in Japan: Recent legal decisions', U.S.-Japan Women's Journal (English Supplement), 5 (1993), pp. 52-68.

${ }^{53}$ Setsu Shigematsu, 'Rethinking Japanese feminism and the lessons of Üman Ribu: Toward a praxis of critical transnational feminism', in Julia C. Bullock, Ayako Kano, and James Welker (eds), Rethinking Japanese Feminisms (Honolulu, Hawai'i: University of Hawai'i Press, 2017), pp. 205-29; Matsui Machiko, 'Evolution of the feminist movement in Japan', NWSA Journal, 2:3 (1990), pp. 435-49.

${ }^{54}$ Setsu Shigematsu, Scream from the Shadows: The Women's Liberation Movement in Japan (Minnesota Scholarship Online, 2012), available at: $\{$ https://minnesota.universitypressscholarship.com/view/10.5749/minnesota/9780816667581.001. 0001/upso-9780816667581-chapter-4\} accessed 10 March 2021.

${ }^{55}$ Ibid.; Andrea Germer, Vera Mackie, and Ulrike Wöhr, Gender, Nation and State in Modern Japan (London, UK: Routledge, 2017).

${ }^{56}$ Yukiko and Mariko, 'Sexual harassment in Japan'.

${ }^{57}$ Mieko Yoshihama, 'Policies and services addressing domestic violence in Japan: From non-interference to incremental changes', Women's Studies International Forum, 25:5 (2002), pp. 541-53; For more on the representation of women as sexual objects, see Tomo Shibata, 'Pornography', Sexual Objectification and Sexual Violence in Japan and in the World (Lund, Sweden: Centre for East and South-East Asian Studies, Lund University, 2008).

${ }^{58}$ Christopher Uggen and Chika Shinohara, 'Sexual harassment comes of age: A comparative analysis of the United States and Japan', The Sociological Quarterly, 50:2 (2009), pp. 201-34.

${ }^{59}$ Ibid.
} 
During the 1990s, the public debate around the 'comfort women' also marked a turning point in Japanese feminism. ${ }^{60}$ While fuelling the feminist debate in Japan, the 'comfort women' issue also came to split and divide feminists in Japan. The opinions of the 'majority Japanese feminists' like Ueno Chizuko became contrasted with those of other feminists, such as Kim Puja, whose argumentation evolved from the experience of being a Korean feminist living in Japan. Ueno was accused of advocating a feminist hierarchy that positioned the importance of gender above ethnicity. ${ }^{61}$

In the 1990s, an interest in gendered and feminist approaches of human rights also gained ground, partly due to immigrant workers engaged in the sex industry in Japan, the issue of the 'comfort women' and the problems of military sexual violence around the bases in different places - among them, Okinawa. This interest was reflected in a book on Human Rights (edited by Watanabe Kazuko) in 1994, which brought together papers on, among other things, feminist approaches to human rights, trafficking of women and sexual violence by military personal. ${ }^{62}$

All in all, during the twentieth century, different events and strands in the feminist debate increased the awareness of sexual abuse more generally. By 2005, the number of filed cases of sexual abuse had increased to the degree that the Japanese Ministry of Health, Labour, and Welfare released a statement to acknowledge sexual harassment as a 'recognizable labour incident'. This development has created an increased consciousness and activism among the younger generations. ${ }^{63}$ As the homepages of organisations such as Women's Action Network (WAN) and the Asian Women's Resource Center reveal, the first decades of the twenty-first century have been the scene of insisting, sometimes small-scaled, and often creative feminist resistance in Japan. ${ }^{64}$ Movie clips, panels and book reviews with feminist considerations have co-existed with more direct political actions, such as the AJWRC-OMCT joint recommendations on the Japanese Military Sexual Slavery. These kinds of feminist actions have been complemented with gatherings; there has been a plethora of feminist demonstrations, cat walks, ${ }^{65}$ and a slut walk. ${ }^{66}$

The above-mentioned events, in combination with less visible epistemic battles, came to form the context of the \#MeToo movement in Japan. ${ }^{67}$ Still, as pinpointed by my respondents, not only does previous resistance against sexual harassment compose a platform for political mobilisations, but so does sexual harassments and stereotyping. ${ }^{68}$ A representative of a Japanese feminist organisation stated that:

if you are asking for events which had more direct influence preceding the (\#MeToo) movement, perhaps we can say that many gender discriminatory events lead to gradual change of the public perception, young people's awareness of the issues and increased media reports. Events such as discriminatory action and comments by politicians, degrading article of popular magazine ranking college by college women most likely/available to have sex, discriminatory handling of medical school entry exams, issue of JK business and online sexual

\footnotetext{
${ }^{60}$ Ulrike Wöhr, 'A touchstone for transnational feminism: Discourses on the comfort women in 1990s Japan', Japanstudien, 16 (2004), pp. 59-90 (p. 66).

${ }^{61}$ Ibid.; Shigematsu, 'Rethinking Japanese feminism and the lessons of Üman Ribu'.

${ }^{62}$ Vera Mackie, Feminism in Modern Japan: Citizenship, Embodiment and Sexuality (Cambridge, UK: Cambridge University Press, 2003).

${ }^{63}$ Uggen and Shinohara, 'Sexual harassment comes of age'.

${ }^{64}$ Asia-Japan Women's Resource Center, available at: \{http://www.ajwrc.org/eng/modules/pico2/index.php?_id=3/\} accessed 1 September 2020; The Worldwide WAN (W-WAN), available at: \{https://wan.or.jp/wwan/\} accessed 1 September 2020.

${ }^{65}$ Author's interview with Asian Women's Resource Center, Tokyo, 2014.

${ }^{66}$ See, for example, Voice Up Japan, available at: $\{$ https://voiceupjapan.org/2020/08/01/japans-first-slutwalk/\} accessed 23 September 2020.

${ }^{67}$ Yukiko and Mariko, 'Sexual harassment in Japan'.

${ }^{68}$ Jacqueline M. Efron, 'The transnational application of sexual harassment laws: A cultural barrier in Japan', University of Pennsylvania Journal of International Law, 20:1 (1999), pp. 133-77 (p. 137).
} 
exploitation of young girls to name a few all seem to have had impact. Of course, actions by different women's groups regarding DV law and revision of criminal law including All Japan Women's Shelter Network can (also) be regarded as a strong underlying driving force promoting the issue (of sexual abuse in Japan). ${ }^{69}$

This quotation points towards the importance of exploring the terrain of sexual violence and the resistance against this violence. The \#MeToo movement in Japan can be understood as a phenomenon with domestic precedents, and it has facilitated and fuelled new forms of activism. Among other things, it formed the seedbed of the Flower Demo's demonstrations, which have taken place since the spring of 2019. Yet another organisation, Voice Up Japan, emerged in early 2019 to push for legal reforms regarding sexual violence in Japan as well as working for a society where people feel safe to voice their experiences of harassment. ${ }^{70}$ As I argue below, this and other organisations complicate the plot of Japanese feminism; they emerge as a new kind of organisation that is established by a 'new' resistance figure.

A common pattern in Japan is that the subject positions of 'mothers' and 'activists' overlap, with many activists being a 'housewife'. ${ }^{71}$ Mikiko Eto, among others, suggests that most campaigners in Japan's anti-nuclear movement are mothers, although Ulrike Wöhr suggests that 'images of masculinity are just as central to pro- as well as anti-nuclear projects'. ${ }^{72}$ Several of my respondents, who were active in different civil society organisations, stated that it is mainly (society-defined) women who participate in their activities. One of the interviewees explained how everyday emotions of fear of pesticides and additives in food evoke political subjectivities and have boosted women's civil society activism due to experiences in their everyday lives:

A lot of people when they cook felt that, especially mothers, that they wanted to eat good food or safe food. Take bananas, they really want to you know that have OK bananas but at the same time there are no organic bananas in the supermarket in Japan. ${ }^{73}$

However, the \#MeToo activists and their successors are not primarily mothers, which invites us to think of resisting subjects in Japan as shifting and multiple. ${ }^{74}$ Altogether, Japan has a long history of more or less visible feminist dissent. By learning from the sketch above, we need to acknowledge how the multiplicity of formal and informal, glaring and hidden acts of feminist resistance co-mingle in Japan. I suggest that the forthcoming analysis should be read in the light of the Japanese history of feminism.

\section{Sexual abuse, the \#MeToo movement and disciplinary responses in Japan: A background}

The \#MeToo movement visibly demonstrated the high number of women exposed to sexual abuse or sexual violence. Sexual violence has been defined by the World Health Organization (WHO) as:

Any sexual act, attempt to obtain a sexual act, unwanted sexual comments or advances, or acts to traffic or otherwise directed against a person's sexuality using coercion, by any person

\footnotetext{
${ }^{69}$ Author's interview with feminist civil society organisation, August 2020.

${ }^{70}$ Voice Up Japan, 'About', available at: \{https://voiceupjapan.org/about/\} accessed 24 August 2020.

${ }^{71}$ Eto, 'Women's movements in Japan'.

${ }^{72}$ Ulrike Wöhr, 'From Hiroshima to Fukushima: Gender in nuclear and anti-nuclear politics', in HCU 3/11 Forum (ed.), Japan's 3/11 Disaster as Seen From Hiroshima (Tokyo, Japan: Soeisha/Sanseido Shoten, 2013), pp. 203-33.

${ }^{73}$ Author's interview with NGO worker in Tokyo, 2014.

${ }^{74}$ For a complex understanding of the history of feminism in Japan, see Shigematsu, Scream from the Shadows; Germer, Mackie, and Wöhr, Gender, Nation and State in Modern Japan.
} 
regardless of their relationship to the victim, in any setting, including but not limited to home and work. ${ }^{75}$

According to this definition, the coercion of sexual violence can encompass varying degrees of force, psychological intimidation, and blackmailing or threats (of physical harm or of not obtaining food, medicine, work, academic grades and so forth). Additionally, sexual violence may also occur when someone is unable to provide consent; that is, if someone is intoxicated, drugged, asleep, or mentally incapacitated.

As Linda White, a Japanese Studies scholar, suggests, sexual harassment in Japan is widespread and that the sexual double standard, 'allows men to make mistakes, cross lines, or rape and abuse without consequence, while condemning women for any sexuality that results from their own self-determination must be confronted'. ${ }^{76}$

While practices of sexual abuse are pervasive, Japanese cultural norms have effectively silenced women and, consequently, the \#MeToo movement failed to produce a mass mobilisation. In the media, Itō Shiori was, in fact, anticipated as the single spokesperson of the \#MeToo movement in Japan. In 2018, she informed the public of the details of how a veteran journalist had raped her a few years earlier. When recalling the events, Itō Shiori said:

On April 4, 2015, as I regained consciousness in a Tokyo hotel room, I was raped by Noriyuki Yamaguchi, a former Washington, DC bureau chief for the Tokyo Broadcasting System and a journalist with close ties to Prime Minister Shinzō Abe.

I met Mr Yamaguchi the night before to discuss work opportunities. My last memory of that evening is feeling dizzy in a sushi restaurant. As I went through the ensuing criminal case proceedings, I came to realize how Japan's system works to undermine survivors of sexual assault. When the arrest was cancelled, I thought my only recourse was to speak to the media.

The investigation was scuttled throughout. This was, I and others suspect, partly due to political pressure, but also because of a medical, investigative, legal and, ultimately, social system that marginalizes and fails victims of sex crimes. I've had to fight every step of the way. ${ }^{77}$

Itō Shiori has repeatedly told her story and continues to work against sexual violence. She explains her persistent resistance against sexual violence by arguing that:

Someone has to talk about it. Even I didn't know what kind of society I was living in (earlier). I thought, when I went to the police station, when I called the rape crisis center, they would help me. But I was shocked. Though Japan is such a modern country, there was literally no support. ${ }^{78}$

\footnotetext{
${ }^{75}$ World Health Organization, 'Sexual Violence', in Understanding and Addressing Violence against Women (Geneva: World Health Organization, 2012), available at: \{https://apps.who.int/iris/bitstream/handle/10665/77434/WHO_RHR_12. 37_eng.pdf;jsessionid=14DCEAB3A3C8570BF9AD5D82AA98CEDE?sequence=1 \} accessed 1 September 2020.

${ }^{76}$ Quoted in Crystal Tai, '\#MeToo is too slow in Japan as peeping Toms come under the spotlight', South China Morning Post (14 October, 2018), available at: \{https://www.scmp.com/week-asia/society/article/2168389/metoo-too-slow-japanpeeping-toms-come-under-spotlight/ $\}$ accessed 15 October 2019.

${ }^{77}$ Shiori Itō, 'Saying \#MeToo in Japan: When it comes to sexual assault and harassment in Japan, a culture of silence prevails', Politico (2 January 2018), available at: $\{$ https://www.politico.eu/article/metoo-sexual-assault-women-rights-japan/\} accessed 15 October 2019.

${ }^{78}$ Quoted in Indulekha Aravind, “I spoke out because someone had to" Japan's face of the \#MeToo movement', The Economic Times (13 December, 2018), available at: \{https://economictimes.indiatimes.com/news/international/world-news/ i-spoke-out-because-someone-had-to-japans-face-of-the-metoo-movement/articleshow/67070739.cms/\} accessed 15 October 2019.
} 
The above quotations clearly display how Itō Shiori interprets the norms of local institutions, which is an analysis that gave rise to different emotions, such as shock and despair. The emotional impact of the experience also contributed to the shaping of her political subjectivity and the reason why she turned to the public about the rape, as 'someone has to talk about it' ${ }^{79}$

Her narrative situates women's bodies in the context of power networks, sexual violence, and struggles of resistance, while also questioning the punishments that are distributed for resisting this violence. According to Foucault, punishments, as disciplinary means, are used to suppress uncomfortable truths and bind individuals to their identities. ${ }^{80}$ In this manner, discipline becomes a way to maintain gendered norms, while delinking norms and practices that do not fit within the limits of the discursive boundaries. Disciplinary punishments are most likely a principal reason as to why the \#MeToo movement, from the start, had a very limited effect on Japan and Japanese society. Liv Coleman, an Associate Professor in Political Science and International Studies who specialises in Japan, has argued that the outspokenness of the \#MeToo movement has been met with disapproval and that, 'when high-profile [alleged] victims such as Itō Shiori have come forward with allegations, they have received a lot of criticism ... This deters other women from bringing forth allegations of sexual harassment and assault.' By the same token, Itō Shiori stated, 'We haven't really had a \#MeToo movement not because victims haven't come forward, but because Japanese society wants them to stay silent. ${ }^{, 81}$

More broadly, feminist-inspired concerns about equality have given rise to various backlashes in Japan and elsewhere. ${ }^{82}$ Ueno Chizuko, Professor Emerita in Sociology, has lately expressed pessimism regarding Japanese feminism, firstly because of Shinzō Abe's return to power, but more generally because of the current rise of populist politics. ${ }^{83}$ As in other regions of the world, the 'gender' ( jendā) concept has evoked reactions in Japanese society. While widely adopted in feminist and scholarly circles, it has stimulated a backlash from ultra-conservatives, who argue against gender equality via reference to cultural destruction. ${ }^{84}$ Roman Kuhar and David Paternotte conclude that anti-gender movements currently move transnationally and regularly present themselves in opposition to clearly identified actors such as feminists, LGBT activists, specific elites and others'. ${ }^{85}$ It is a new form of activism that is against, among other things, gender ideology, gender mainstreaming, and gender studies. ${ }^{86}$

In this context it is understandable that more anonymous forms of gendered resistance have attracted feminists in Japan. For example, in 2014 a group of women in Tokyo threatened a 'sex boycott' against any man who voted for candidate Masuzoe Yōichi for governor of Tokyo. Yōichi, among other things, has claimed that it is improper to have women at the highest level of government since their menstrual cycle makes them irrational. The protest against Yōichi was initiated by a Tokyo-based Twitter campaign group, which describes itself as 'the association of women who will not have sex with men who vote for Masuzoe'. The call garnered almost three thousand followers who followed its launch at the beginning of February 2014. The resistance initiative's anonymous founders stated in their Twitter profile: 'We have stood up to prevent

\footnotetext{
${ }^{79}$ Itō, 'Saying \#MeToo in Japan'.

${ }^{80}$ Foucault, Discipline and Punish.

${ }^{81}$ Itō, 'Saying \#MeToo in Japan'.

${ }^{82}$ Susan Faludi, Backlash: The Undeclared War against American Women (New York, NY: Crown Publishers, 1991); Nancy Fraser and Rahel Jaeggi, Capitalism: A Conversation in Critical Theory (London, UK and New York, NY: Verso, 2018).

${ }^{83}$ Ayako Kano, 'Conclusion: On rethinking Japanese feminisms', in Bullock, Kano, and Welker (eds), Rethinking Japanese Feminisms, pp. 267-82.

${ }^{84}$ Mikiko Eto, “'Gender” problems in Japanese politics: A dispute over a socio-cultural change towards increasing equality', Japanese Journal of Political Science, 17:3 (2016), pp. 365-85.

${ }^{85}$ Roman Kuhar and David Paternotte, 'The anti-gender movement in comparative perspective', in Roman Kuhar and David Paternotte (eds), Anti-Gender Campaigns in Europe Mobilizing against Equality (London, UK and New York, NY: Rowman \& Littlefield, 2017), pp. 253-72.

${ }^{86}$ Ibid., pp. $258-9$.
} 
Mr Masuzoe, who makes such insulting remarks against women [from being elected] ... We won't have sex with men who will vote for Mr Masuzoe.'

As it emphasises a boycott, this particular resistance practice may be regarded as 'noncooperative', while drawing on images of the sexually active man. The fact that the sex boycott was anonymous could be comprehended as an attempt to avoid disciplinary punishments. As illustrated above, many of the reactions against Itō Shiori, including responses from other women, were hostile. She was told that:

A Japanese person wouldn't talk about that in public; that she must be a prostitute; to 'go back to Korea'. I was vilified on social media and received hate messages and emails and calls from unknown numbers. I was called a 'slut' and 'prostitute' and told I should 'be dead'. There were arguments over my nationality, because a true Japanese woman wouldn't speak about such 'shameful' things. Fake stories popped up online about my private life with photos of my family. I received messages from women criticizing me for failing to protect myself. $^{87}$

This quotation should be read in the broader context of the 'comfort women' controversy; that is, the 200,000 Asian women, many of them Korean, mentioned above, who were sent to military brothels to sexually serve Japanese soldiers during the Asian-Pacific War. The discourses tied to this practice seemingly inform the way in which Itō Shiori has been slandered since coming out to the media with her story. ${ }^{88}$ Overall, Itō Shiori experienced that she was punished for talking about the suffering of her sexual violence encounter. Similarly, one of my respondents stated that:

It might be hard for you to understand, but in Japan historically the victims of rape/sexual violence are the ones who would be blamed. So, a majority of the victims have been silent, and Shiori is a kind of exception. ${ }^{89}$

The punishment delivered for challenging Japanese gender norms is connected to the recognition of certain performances of femininity as 'Japanese'. Resisting the powers that subjugate women into docility, for some, seemingly falls outside the performances of 'Japanese women'.

The strong reactions against the \#MeToo movement in Japan can be understood through previous research, which has shown how women's movements possess the ability to empower women in politics, as well as to negotiate dominant norms and women's exclusion from formal politics. For example, Joyce Gelb and Marian Lief Palley have analysed the successes of American second-wave feminist movements in securing public policy changes between 1974 and 1984, and they established that possible success depended on various factors. ${ }^{90}$ The feminist groups that had the greatest effect were the ones who were able to establish broad-based support outside the feminist circles. ${ }^{91}$ These groups avoided political struggles around issues that challenged fundamental values around which supporters' views were likely to be polarised. Instead, these groups selected narrow issues that presented limited challenges to their supporters. However, in Japan, the \#MeToo campaign, as it appears, contested what people experienced as fundamental values

\footnotetext{
${ }^{87}$ Itō, 'Saying \#MeToo in Japan'.

${ }^{88}$ Pyong Gap Min, 'Korean “comfort women”: The intersection of colonial power, gender, and class', Gender \& Society, 17:6 (2003), pp. 938-57.

${ }^{89}$ Author's interview (via Messenger) with civil society member, Japan, 2020; The silence around sexual abuse in Japan is also elaborated by a number of feminist Japanese scholars, see, for example, Yumi E. Suzuki, 'Sexual violence in Japan: Implications of the lay judge system on victims of sexual violence', Journal of Law and Criminal Justice, 4:1 (2016), pp. 75-81; Yoshihama, 'Policies and services addressing domestic violence in Japan'.

${ }^{90}$ Joyce Gelb and Marian Lief Palley, Women and Public Policies: Reassessing Gender Politics (Charlottesville, VA: University Press of Virginia, 1996).

${ }^{91}$ Ibid.; Lilja and Johansson, 'Feminism as power and resistance'.
} 
and, as a result, invoked the mobilisation of strong counter-reactions. This most likely lessened the campaign's effectiveness.

The silencing of narratives of sexual abuse and the non-stories of the Japanese \#MeToo movement have been addressed by Itō Shiori, as well as other women who embraced the \#MeToo campaign. She stated that:

Japan hasn't had a big \#MeToo movement, but what's happened in the United States and elsewhere has provided an opening in our media to discuss sexual harassment and assault here, and to raise awareness. Some well-known authors - Mayumi Mori and Kyoko Nakajima, who contributes to Asahi newspaper, for example - have criticized society's silence and are writing about their own stories of harassment. ${ }^{92}$

The above suggests that (self-identified and society-defined) women in Japan more generally, when reading the representations of the \#MeToo campaign, responded with resistance as well as passivity. This can be understood through current discourses on agency within IR Feminism. Researchers, such as Maria Stern, Stina Hansson, and Sofie Hellberg have elaborated on 'the agency of being governed', arguing, in accordance with Saba Mahmood, that agency is not solely located within resistance, but also within compliance. ${ }^{93}$

While Japan's \#MeToo campaign had a limited impact, according to Itō Shiori, the raising of her voice, as well as other actors' voices, nevertheless succeeded to promote alternative discourses of gender, which resulted in legislative changes. ${ }^{94}$ When responding to the following question, 'Were there any changes made to the law, after you spoke out?', she said:

It was not just because of me but yes, finally, after 110 years, they changed the rape law. They changed the minimum jail sentence for rape from three years to five. Earlier, it was less than the sentence for burglary. The definition was also expanded but you still need to prove how much you were threatened and violated. And our age of consent still remains 13 years. It is really difficult to prove consent here. ${ }^{95}$

Moreover, in December 2019, Itō Shiori won her case at the Civil Court. According to the homepage of Flower Demo, the verdict does not only acknowledge her struggle but also all the victims of sexual violence who are still suffering. It is a sign that the struggle has resulted in some social change:

Such a ruling might not have been obtained a year ago. The ruling made us feel the hope in which the voices of the sexual assault victims have changed society. Raising our voice is not a waste. We can make a change. ${ }^{96}$

When viewed through the prism of constructive resistance, this quotation supports the overall conclusion drawn by both previous research and my respondents; the recognising and

\footnotetext{
${ }^{92}$ Itō, 'Saying \#MeToo in Japan'.

${ }^{93}$ Saba Mahmood, Politics of Piety: The Islamic Revival and the Feminist Subject (Princeton, NJ: Princeton University Press, 2005); Maria Stern, Stina Hansson, and Sofie Hellberg, 'Introduction', in Studying the Agency of Being Governed (New York, NY: Routledge, 2015).

${ }^{94}$ For more information on legislative measures on sexual harassment in Japan, see Catherine Burns, Sexual Violence and the Law in Japan (London, UK: Routledge, 2005); Suzuki, 'Sexual violence in Japan'; Ryuichi Yamakawa, 'We've only just begun: The law of sexual harassment in Japan', Hastings International and Comparative Law Review, 22:3 (1998), pp. 523-63 (p. 523); Uggen and Shinohara, 'Sexual harassment comes of age'; Efron, 'Transnational application of sexual harassment laws', p. 133.

${ }^{95}$ Aravind, "'I spoke out because someone had to"'.

${ }^{96}$ Flower Demo, 'About', available at: \{https://www.flowerdemo.org/about-us-in-english $\}$ accessed 24 August 2020.
} 
naming of sexual abuse have provided a fertile ground for new practices, as well as new ways of talking and thinking. ${ }^{97}$

\section{The \#MeToo campaign as constructive resistance}

The above discussion has presented an overview of Japan's \#MeToo movement, as well as the resistance against it. The section below offers a more detailed discussion of the \#MeToo movement as a constructive form of resistance and an analysis of the alternative narratives and subject positions of \#MeToo. A section that reveals the hashtag as a new configuration of feminist resistance follows. These images, configurations, and discourses must be, however, as suggested in the introduction, seen as both contested as well as unstable constructions rather than dominant or clear-cut.

\section{New narratives of the \#MeTOo movement as a form of constructive resistance}

As elaborated above, the \#MeToo movement more generally prevailed as a form of resistance that circulated among those who recognised and embraced its message. ${ }^{98}$ This circulating, and by extension constructive resistance of the \#MeToo movement, worked through narratives that inspired new narratives; it was resistance that generated new resistance. Doublings and (re) repeated stories gave rise to (re)experiences, (re)constructions and the upholding of the \#MeToo discourse. Such narrating appeared as an unstable process whereby discourse became a source, an instrument and an effect of resistance. In many venues, the narratives of sexual abuse produced new discourses and could, therefore, be comprehended as a constructive form of resistance, which produce alternatives to establish truths. Accordingly, my respondents (as well as previous research) concluded that the \#MeToo movement has made sexual abuse increasingly intelligible in a Japanese context. ${ }^{99}$ This can be illustrated by a quote by Itō Shiori, who stated with regards to her family:

[My family] had a difficult time, they never wanted me to do this ... to speak about it in public. They were also scared about what would happen to them because he [the accused, journalist Yamaguchi] is a very powerful person. It took time to start communicating with my family again but the \#MeToo movement helped. It made them realise I was not the only one. ${ }^{100}$

As Ninni Carlsson has displayed in her research on narratives of being sexually abused, one precondition for recognition of and the success in mobilising a political question is a certain discursive preparedness for this and/or similar questions. ${ }^{101}$ In order to be recognised, a group that advances a new narrative must already have a certain influence and power over the dominant discourses. In this sense, the \#MeToo campaign could be understood as being a result of feminist discursive power but also of female subordination. ${ }^{102}$ On a global scale, the resistance of the \#MeToo movement was, thereby, productive of new, but still discursively anchored, narratives

\footnotetext{
${ }^{97}$ See, for example, Linda Hasunuma and Ki-young Shin, ‘\#MeToo in Japan and South Korea: \#WeToo, \#WithYou', Journal of Women, Politics \& Policy, 40:1 (2019), pp. 97-111.

${ }^{98}$ Lilja and Johansson, 'Feminism as power and resistance'; V. Jo Hsu, '(Trans)forming \#MeToo: Toward a networked response to gender violence', Women's Studies in Communication, 42:3 (2019), pp. 269-86, available at: \{https://doi.org/ 10.1080/07491409.2019.1630697\}.

${ }^{99}$ Ibid.; Lilja and Johansson, 'Feminism as power and resistance'.

${ }^{100}$ Quoted in Aravind, “I spoke out because someone had to"'.

${ }^{101}$ Ninni Carlsson, Avslöjandets tid: Kvinnors bearbetning av sexualla övergrepp [Times of Revelation: Women's Processing of Sexual Abuse] (Gothenburg, Sweden: Gothenburg University, 2009).

${ }^{102}$ Lilja and Johansson, 'Feminism as power and resistance'.
} 
of sexual abuse. Such narratives challenged previous cultures of silence, but were still read as comprehensible and understandable within the context that they appeared.

However, as suggested above, the narratives of the \#MeToo campaign were not generally discursively recognisable or intelligible on a local basis in Japan once the movement reached the country. Rather, the campaign appeared, by some, to be untrue, irrelevant, insane, or excessively shameful, and thereby displays sexual abuse as situated outside of the boundaries of the (prevailing) discourses. Regardless, by time, the narratives were established and it was possible for Itō Shiori's family to make sense of her acts from the viewpoint of the \#MeToo discourse as it was further advanced.

Moreover, the \#MeToo movement created a non-organised but organic community of belonging when individual resistance was undertaken as a serial phenomenon. For example, as emphasised by Itō Shiori, certain well-known authors, among them Mayumi Mori and Kyoko Nakajima, wrote their stories of harassment and criticised society's silence in connection to the \#MeToo campaign. By noting this, Itō Shiori connected these women to each other and identified a community of women who were fighting against the silence surrounding sexual abuse. The individual acts of resistance of the \#MeToo campaign were, by connecting these women to each other and the sexual abuse issue, embedded in a collectiveness.

Thus, the \#MeToo movement's resistance prevails as both individual and collective, as well as transnational and local. The \#MeToo movement was a constructive form of resistance, in the sense that it connected people to each other, created communities of belonging and decided who the victims and perpetrators were. It was, initially, repeated by Itō Shiori together with others who, while sharing their stories, constructed an image of an alternative future reality - an imaginary future that includes both mental and legal support to those who are victims of sexual abuse. For example, when Itō Shiori won the court case (December 2019) against the television anchor she alleges raped her, she said that she, "hoped the case would change ... the "under-developed" legal and social environment surrounding rape in Japan'. ${ }^{103}$

Today, the \#MeToo narrative is recapped and reinvented in Japan by organisations such as Voice Up Japan, Spring, or 'Human Rights Now' and Flower Demo. ${ }^{104}$ According to the latter's homepage:

It has been said that \#MeToo will not start in Japan. Some say that Japanese women are not strong enough. But \#MeToo's voice would not have been raised if there was no one listening or believing in your voice. That is why we have decided to have a flower as a symbol of \#WithYou. ${ }^{105}$

Several respondents stated that the \#MeToo movement has inspired other organisations to become established, which in turn has impacted upon the awareness of sexual abuse. When I interviewed an activist at Flower Demo, she suggested that the specific resistance of the movement has changed the discourses of the Japanese society:

In Japan, the voices of victims of sexual violence have not been heard. However, when the flower demonstration began, major media talked about it recently. And the Law Amendment Commission began. We believe Flower Demos will change the consciousness of society. ${ }^{106}$

\footnotetext{
${ }^{103}$ Japan journalist wins case against reporter with links to PM Abe', NDTV (18 December 2019), available at: \{https:// www.ndtv.com/world-news/japan-journalist-shiori-ito-wins-metoo-case-against-reporter-with-links-to-pm-shinzo-abe$2150655\}$ accessed 3 September 2021.

${ }^{104}$ See, for example, 'The \#MeToo Movement in Japan', available at $\{$ https://www.youtube.com/watch?v=GuFK4jxRl1g\} accessed 1 September 2020.

${ }^{105}$ Flower Demo, 'About'.

${ }^{106}$ Author's interview with Flower Demo activist, 10 September 2020.
} 
Another respondent similarly stated, in regard to Voice Up Japan, that: 'a new group named Voice Up Japan has launched by initiative of young girls. These streams are still small, but they would bring changes to the Japanese society gradually, I believe. ${ }^{\prime 107}$

These and other quotations suggest that the \#MeToo discourse is still repeated in Japan but now in the format of, among other things, Flower Demo and Voice Up Japan. The \#MeToo movement in Japan - even though it was initially not composed of many testimonies expressed by many subjects - has, by time, come to be repeated in new versions of new (collective) actors and in new venues. Each statement against sexual abuse can be seen as part of the production of a discourse against sexual abuse, which is not only (re)created but also maintained over time. In this regard, each statement on sexual abuse is to be seen as a special case of constructive resistance - they are repetitions that are provoked by other repetitions, while containing both similarities and differences to previous expressions. As argued above, although constructive resistance can be collectively organised and on a grand scale, ${ }^{108}$ it may also be - as is apparent in the case of the \#MeToo movement - a matter of producing ongoing small-scale differences that might appear trivial, yet still hold the potential to create a major societal effect.

\section{A new configuration of resistance}

As suggested above, new yet unstable truths were constructed via the \#MeToo campaign. To this can be added that the specific configuration that the \#MeToo symbol composes has also been instituted in Japan as an established yet alternative form of resistance. Using a hashtag has become a recognisable way of protesting against unequal gender relations. Flower Demo has, as stated above, complemented the \#MeToo hashtag with the sign \#WithYou, which is meant to support the \#MeToo campaign. ${ }^{109}$ On the homepage of Flower Demo, it is stated that, 'we have decided to have a flower as a symbol of \#WithYou, saying "we believe you and we are always on your side"'. ${ }^{110}$ Here, the \#WithYou hashtag has an ambivalent appearance; it looks similar to the \#MeToo hashtag and shows up in feminist discourse as a form of dissent; still, it is not the same hashtag but it carries a new but related meaning.

Moreover, the \#MeToo campaign's formula has also been adopted, although filled with a new and alternative meaning, in the \#KuToo online movement. This social media hashtag is a reference to the Japanese words for shoes (kutsu) and pain $(k u t s \bar{u})$. A Japanese woman, Ishikawa Yumi, initiated the campaign by tweeting about the dress code for high-heeled shoes, which is mandatory for many women in the workforce. The tweet received over 67,000 likes and almost 30,000 retweets. Ishikawa also launched a petition against the forced wearing of high-heeled shoes in the workplace, which received approximately 20,000 signatures. ${ }^{111}$ The Japanese Labour Minister, Nemoto Takumi, responded, and despite the campaign's persistence, he indicated that he would not support a drive to ban such dress codes, stating that, 'It's generally accepted by society that [wearing high heels] is necessary and reasonable in workplaces. ${ }^{112}$ The \#KuToo campaign can be read as borrowing the format of the \#MeToo movement and blending its configuration of resistance with a new message with new senders. This was recognised by one of my respondents, who stated, 'I believe Shiori's struggle had a certain impact to Japanese women, especially to young generation (such as) \#KuToo ....'113

\footnotetext{
${ }^{107}$ Author's (via Messenger) interview with NGO worker, Tokyo, 2020.

${ }^{108}$ Sørensen, 'Constructive resistance'.

${ }^{109}$ Author's interview (via Messenger) with NGO worker in Tokyo, 2020.

${ }^{110}$ Flower Demo, 'Home', available at: \{https://www.flowerdemo.org\} accessed 7 September 2020. Similar findings have been made by Hasunuma and Shin, '\#MeToo in Japan and South Korea', p. 105, who discuss the concept of \#WeToo.

${ }^{111}$ Toma Mochizuki, 'Men force feet into high heels as Japan's \#KuToo movement seeks to build on media attention', Japan Times (10 June 2019), available at: \{https:/www.japantimes.co.jp/news/2019/06/10/national/social-issues/men-forcefeet-high-heels-japans-kutoo-movement-seeks-build-media-attention/\#.XRCIuy2HKjR/\} accessed 15 October 2019.

${ }^{112}$ Ibid.

${ }^{113}$ Author's interview (via Messenger) with NGO worker in Tokyo, 2020.
} 
The \#KuToo resistance lends distinguishable elements from the 'original' resistance through references to it, while being contextually distinct from it. Such replication makes us re-experience the configuration, while still loading it with new political messages. The new repetition of the specific configuration of the \#MeToo movement's resistance depends on both sameness and differences, in addition to creativity and variation. The repetition in itself should be seen as constructive resistance, producing an alternative, yet unstable, sign vehicle.

By the same token as the \#MeToo campaign, the \#KuToo campaign is not simply a local phenomenon, but must be placed within the context of a transnational movement against women's dress codes. For example, at the 2016 Cannes Film Festival in France, Julia Roberts and numerous other actors walked the red carpet barefoot or in sneakers in order to throw light on the event's dress code. Thus, the campaign, like the \#MeToo movement, reflects the traffic of narratives transnationally, and how these narratives are read, as well as how meanings are lost in the translation, while crossing geopolitical and cultural borders. The \#MeToo movement was a hashtag that emerged in a particular geopolitical space and was thereafter trafficked, consumed, repeated, understood, as well as resculptured in different geographies. The enactment of the hashtag in new locations and its transnational crossings were made possible by digital platforms such as Twitter, which created agency as well as friction.

More generally, the above indicates that the \#MeToo movement's format has been institutionalised in Japan as a specific configuration of resistance, which is now adopted more pervasively as a political strategy. Over and above the \#WithYou and \#KuToo campaigns, the hashtag format of the \#MeToo movement has been reused and reformulated as a reaction against Kim Kardashian West's new shapewear brand, Kimono Intimates (\#KimOhNo). ${ }^{114}$ Due to the accusations of cultural appropriation, Kim Kardashian West later changed the name of her new underwear. $^{115}$

The reinvented hashtags are not simply passive containers of different meanings, and do not simply represent discourses but also partake in the ongoing processes of establishing different truths and norms, while at the same time, drawing attention to, and in some senses repeating, the \#MeToo discourse. ${ }^{116}$ Taking stock of recognised symbols to establish new discourse of resistance is a powerful strategy of constructive resistance.

\section{The new campaigners}

The above discussion reveals how the configuration of the \#MeToo hashtag has been reused, redesigned and refilled with new meaning. Of further note is that even if it is not a widely held perception, Itō Shiori ultimately has contributed to advancing an alternative figure of resistance. As suggested previously, resistance in Japan is sometimes understood as a caring practice through which mothers attempt to fight against food producers, the state, and multinational farmers. ${ }^{117}$ The pattern of women resisting has been prevalent since the 1960 s and is, as Eto

\footnotetext{
${ }^{114}$ Stuart Hall, 'The work of representation', in Stuart Hall (ed.), Representation: Cultural Representation and Signifying Practices (London, UK: Sage, 1997).

${ }^{115}$ 'Kim Kardashian West drops "kimono" name from underwear line as Japan accuses her of cultural appropriation', CBS News (2 July 2019), available at: \{https://www.cbsnews.com/news/kim-kardashian-west-shapewear-drama-kimono-underwear-fashion-line-japan-cultural-appropriation/\} accessed 15 October 2019.

${ }^{116}$ See also Judith Butler, Undoing Gender (New York, NY and London, UK: Routledge, 2004); Karen Barad, 'Posthumanist performativity: Toward an understanding of how matter comes to matter', in Stacy Alaimo and Susan Hekman (eds), Material Feminism (Bloomington, IN: Indiana University Press, 2008), pp. 120-54; Chantal Mouffe, 'Hegemony and new political subjects', in James Martin (ed.), Hegemony, Radical Democracy, and the Political (London, UK: Routledge, 2013), pp. $45-57$.

${ }^{117}$ Eto, 'Women's movements in Japan'; David H. Slater, Rika Morioka, and Haruka Danzuka, 'Micro-politics of radiation', Critical Asian Studies, 46:3 (2014), pp. 485-508.
} 
clarifies, linked to the image of women as self-sacrificing and altruistic. ${ }^{118}$ Overall, political subjectivities and resistance in Japan sometimes become entangled with, and emanate from, discourses of caretaking. This caretaking is both universal in character - as in mothers' responsibility for all children - and particular, as the mother is cooking particular food for specific kids. From the above it follows that discourses of femininity (regularly connected to the private sphere) fuel another subjectivity of activism and public involvement. As a form of resistance, the \#MeToo movement appeared to 'fit' poorly, if at all, with this strand of resistance and activism. One of my respondents argued:

We have been working with consumers cooperative and women/mothers are actively taking part in our activities. They are concerned about the society, not only the healthy food for their own families, but many of them are joining anti-nuclear movement or anti-war/peace movement [for their kids' sake]. However, I see that feminism or the \#MeToo movement is not their main concern. Why? One reason that I think is their status as housewives. ${ }^{119}$

Likewise, The Japan Times, pointed this out by stating:

Under the influence of familistic policies legislated by postwar movements into the 1980s, much civil society activity by women in Japan has been undertaken by housewives in neighbourhood associations, or in grassroots food safety and family welfare organizations. Such organizations have little interest in activism against sexual violence and discrimination. ${ }^{120}$

Concurrently, the resistance of the \#MeToo movement contributed to the establishment of alternative resistant figures, such as Ishikawa Yumi (who has been tweeting the hashtag \#KuToo) or Itō Shiori, who stand in stark contrast to the 'mothering' dissent that is played out by many housewives. While feminist resistance has a long history in Japan, Itō Shiori and other highprofile women have strengthened an alternative resistance figure whose crucial stakes are not attached to practices of mothering. In addition, the \#MeToo movement has provided the seed bed for a new type of organisation, among them the Flower Demos, Spring, and Voice Up Japan, who do not primarily base their activism on parenting, but around issues such as sexual abuse, women politicians or gay marriage. When interviewing Voice Up Japan, they told me that:

These initiatives (the Flower Demos, the Slut Walk in Osaka and the Voice up Japan) definitely started from, and got inspired from, the \#MeToo ... These organisations are working together. For example, the Voice up Japan has been invited several times to the Flower Demos. So, we act together in many projects. ${ }^{121}$

Another of my respondents stated:

Men lead movements and celebrities and academics, but these new movements are totally different. It is women who lead these movements ... Flower Demos, Spring, and Voice up Japan: it is new kind of people, ordinary women and survivors of sexual abuses, who lead these movements. ... The Japanese women's movement has been dominated by older

\footnotetext{
${ }^{118}$ It is also: 'easier for Japanese women to speak out as mothers than as women, since women themselves are still regarded as "second-class citizens" whose voices are socially and politically neglected'. See Eto, 'Women's movements in Japan', pp. 317-18.

${ }^{119}$ Author's interview (via Messenger) with NGO worker in Tokyo, 2020.

${ }^{120}$ Shawn O'Dwyer, 'What lies behind Shiori Ito's lonely \#MeToo struggle', Japanese Times (26 January 2020), available at: \{https://www.japantimes.co.jp/opinion/2020/01/26/commentary/japan-commentary/lies-behind-shiori-itos-lonely-metoostruggle/\} accessed 1 September 2020.

${ }^{121}$ Author's interview (via Google Meet) with Voice Up Japan, 1 October 2020.
} 
women. This time it is younger women and students, who take the lead. The young generation raises their voice: that is a unique situation. ... After the \#MeToo these organisations started to speak up. You can say that they were empowered by the \#MeToo movement. ${ }^{122}$

These accounts indicate that while the \#MeToo movement did not gather many followers at the time, it can still be read as a form of constructive resistance that led to a new generation of young people launching new political paths in Japan. New subject positions and organisation have been created in the wake of the transnational movement, as well as Itō Shiori's and other's struggles, to obtain redress and justice.

\section{Conclusion}

As suggested above, studies of resistance in IR have contributed with several insights regarding different forms of resistance (organised and individual, overt or covert) as well as the crossroads between power and resistance; still, one weakness of the scholarship, in most studies, is the conspicuous absence of the productive aspects of dissent. There is some research on the production of alternative institutions and some that elaborate on discursive forms of resistance; however, as argued in this article, constructive resistance is productive of both institutions, as well as of discourses and subject positions. By analysing the \#MeToo movement in Japan, I display the richness of constructive resistance. The campaign provided a significant example of how new discourses may move transnationally through the power of repetition. It may be perceived as a contagious form of resistance, which operated through reiterations, doublings, and re-experiences. In Japan it was productive of new discourses, activist subject positions, and configurations, still, I would like to argue that this resistance also carried non-cooperative elements, which challenged established social norms and legal processes.

Moreover, the \#MeToo movement revealed some mechanisms of constructive resistance. The current upswing of feminist organisations in the aftermath of the \#MeToo campaign could be understood as a new generation of feminists, who reframe the Japanese feminist discourse from a new venue and from new subject positions. As it appears, young activists transform the political terrain by (re)constructing the \#Metoo discourse into, among others, a \#WithYou discourse. The repetitions of the \#MeToo discourse that are done in slightly different ways, can be seen as a strategy of constructive resistance. Repetitions, and how these are formulated, inform both the content and impact of feminist discourses. ${ }^{123}$ Still, the (\#WithYou) (re)formulation of the \#MeToo discourse is probably contaminated with power, which punishes victims of sexual abuse, who are themselves blamed for the violence. A reformulation that supports the victims is probably less 'dangerous' in a Japanese context.

As indicted above, repetitions encourage repetitions, thus being an engine and means in constructive resistance. This repetitive force could be explained by the fact that representations create norms that, in turn, produce more repetitions. Gilles Deleuze also argues that repetitions make us expect new repetitions, which maintain different patterns. ${ }^{124}$ Thus, repetitions lead to new reiterations, which establish orders and cemented norms and make repetitions even more interesting. ${ }^{125}$

In this process, the \#MeToo hashtag was established as a new 'resistance sign' - the hashtag was transformed and added new meaning in other resistance campaigns, such as the \#WithYou, \#KuToo, or \#KimOhNo. Through the use of an established sign - a hashtag - which is recognisable and therefore effective in different epistemic battles, these movements came to produce

\footnotetext{
${ }^{122}$ Author's interview (via Zoom) with Kazuko Ito, Human Rights Now, October 2020.

${ }^{123}$ Eva Lilja and Mona Lilja, 'Linguistic resistance: Establishing, maintaining and resisting truths', Journal of Resistance Studies, 4:1 (2018).

${ }^{124}$ Gilles Deleuze, Difference and Repetition (New York, NY: Columbia University Press, 1994 [orig. pub 1968]).

${ }^{125}$ Mona Lilja and Mikael Baaz, 'Resistance, rupture and repetition: Civil society strategies against intimate partner violence in Cambodia', Global Public Health, 11:1-2 (2016), pp. 95-107.
} 
alternative discourses. This can also be read as a strategy of hybridity, in which the \#MeToo hashtag has merged with new resistance discourses. It is constructive resistance that employs but still negotiates the \#MeToo sign.

The above-mentioned effects of the \#MeToo discourse depend upon two interlinked steps. Firstly, the \#MeToo discourse as it was established abroad, when repeated in Japan, came to establish a new discourse on sexual abuse and 'new' resistance subjects. In a second step, however, the discourse was reinterpreted and begun to take new forms (for example, \#WithYou) in the specific Japanese context; that is, the terrain in which the hashtag was negotiated and reinterpreted. When assumed and negotiated locally, the movement came to be the seedbed of new configurations of resistance as well as new generation of resistance organisations that, in turn, appear to have reinvented Japanese feminism. Thus, the constructive resistance that is illuminated in this article stems from different forms of crossing and lending of knowledge in different contexts. The above implies that reinterpretations and the reinvented repetition of the \#MeToo discourse, which emerged through contextual (de)coding processes, have been important parts of the constructive resistance of the Japanese \#MeToo movement.

Acknowledgements. I would like to express our sincere gratitude to the anonymous reviewers for their very helpful comments. This article was written within a research programme funded by the Swedish Research Council. Project title: 'Resistance and its Impact on Processes of Democracy'. Project Number: 2017-00881.

Mona Lilja currently serves as a Professor of Peace and Development Research at the School of Global Studies, University of Gothenburg, Sweden. Lilja's area of interest is the linkages between resistance and social change as well as the particularities the character and emergence - of various forms of resistance. She is the author of the recently published book Constructive Resistance: Repetitions, Emotions, and Time (Rowman \& Littlefield International, 2021).

Cite this article: Lilja, M. 2022. Pushing resistance theory in IR beyond 'opposition': The constructive resistance of the \#MeToo movement in Japan. Review of International Studies 48, 149-170. https://doi.org/10.1017/S0260210521000541 